Editöre mektup-Letter to the Editor

http://dx.doi.org/10.7197/1305-0028.1613

\title{
Toraks vasküler anomalileri ve Bilgisayarlı tomografi
}

\section{Thorax vascular anomalies and Computed tomography}

\section{Mehmet Haydar Atalar*}

Radyoloji Anabilim Dalı (Doç. Dr. M. H. Atalar), Cumhuriyet Üniversitesi Tıp Fakültesi, TR58140 Sivas

Geliş tarihi/Received: 23 Haziran 2012; Kabul tarihi/Accepted: 25 Ocak 2013

*İletişim adresi:

Dr. Mehmet Haydar Atalar, Radyoloji Anabilim Dalı, Cumhuriyet Üniversitesi Tıp Fakültesi, TR58140 Sivas. E-posta: mhatalar@gmail.com

\section{Sayın Editör,}

Derginizde, Sayın Eren ve ark. [1] tarafindan yayınlanan "Dev innominate arter anevrizmasına bağlı solunum yetmezliği" başlıklı olgu sunumunu ilgiyle okudum. Olgu genel anlamda iyi tanımlanmış olmakla birlikte önemli olduğunu düşündüğüm birkaç noktayı bilgilerinize sunmak istiyorum. Makalede tanımlanan olgunun innominate arter orijinli bir anevrizma olgusu olduğu belirtilmekle birlikte mevcut aksiyel planda yapılmış olan kontrastlı toraks bilgisayarlı tomografi (BT) incelemede anevrizmatik yapının trakea ve özofagusu öne ve sol laterale doğru deplase ve komprese ettiği ve ağırlıklı olarak sağ yerleşimli olduğu dikkat çekmektedir. Bu durum anevrizmanın dev boyutlarda olmasına bağlı olabileceği gibi, dikkatli bir bakıda olgunun innominate arter kökenli bir anevrizma yerine aberran yerleşimli sağ subklaviyen arterin anevrizması olabileceği de öncelikli olarak düşünülmektedir. Olguya ait koronal ve sagital multiplanar BT görüntülerinin ve üç boyutlu BT-anjiyografik kesitlerin makale içerisinde yer almaması böyle bir tanıyı da olası kılmaktadır. Tanısı ağırlıklı olarak radyolojik bulgular üzerinden konulan bu tip olgularda radyolojik değerlendirmenin dikkatli ve ayırıcı tanıya yönelik yapılması tanısal doğruluk açısından son derece önemlidir.

Sonuç olarak, çoğunlukla asemptomatik olan ve tesadüfen tanı alan aberran sağ subklaviyen arterin hem kendisi hem de gelişebilecek anevrizmatik dilatasyonu, özofagus ve trakeaya bası yaparak semptomatik hale gelebilir. Açıklanamayan disfaji ve dispne olgularında, vasküler anomalilerden de şüphelenilmeli ve tanı multiplanar BT kesitleri ve BT-anjiyografi ile doğrulanmalıdır. Özellikle BT-anjiyografi, vasküler yapıların ayrıntılı anatomisini ve komşu organlarla ilişkilerini gösterebilme yeteneğindedir ve bu yetenek aortik ark anomalilerinin değerlendirilmesinde BT-anjiyografinin diğer görüntüleme yöntemlerine olan en önemli avantajıdır [2, 3].

\section{Kaynaklar}

1. Eren ŞH, Korkmaz İ, Kukul Güven FM, Türkdoğan A, Beydilli İ, Yıldırım B. Respiratuar distress due to giant innominate artery aneurysm. Cumhuriyet Tip Derg 2012; 34: 222-5.

2. Yang $\mathrm{MH}$, Weng $\mathrm{ZC}$, Weng $\mathrm{YG}$, Chang HH. A right-sided aortic arch with Kommerell's diverticulum of the aberrant left subclavian artery presenting with syncope. J Chin Med Assoc 2009; 72: 275-7.

3. Hassan W, Omrani AA, Neimatallah M, Fadley FA, Halees ZA. Dysphagia lusoria caused by aberrant right subclavian artery, Kommerell's diverticulum, legamentum ring, right descending aorta, and absent left pulmonary artery: a report of a unique vascular congenital disease undetected until adulthood and a review of the literature. Pediatr Cardiol 2005; 26: 851-5. 